Chapter 9

\title{
DJ and MC Habitus and 'Skillz' in Peer-led Learning Cultures
}

Garth Stahl and Pete Dale

The aim of this chapter is to use Pierre Bourdieu's theoretical tools to explore identity practices in relation to musical learning practices for working-class boys experiencing extreme levels of disadvantage. In order to expand our understanding, we draw on recent theorizing around the relationship between gender identity and habitus (McNay, 1999; Thorpe, 2010; Adkins, 2003; Coles, 2009) to show how the masculine habitus was significantly altered through the musical practices of MCing and DJing. While boys are often characterized as reluctant learners (Mac an Ghaill, 1988; Jackson, 2003), this cannot be understood without reference to the immediate context, as habitus always operates in relation to field and is where identity is formed (Reay, 2010). In our analysis, we identify three interrelated key features to explore how identity is influenced by the learning culture. After a discussion of the usefulness of Bourdieu's tools in our research, the chapter concludes with some of the implications of this analysis for working with disengaged boys.

\section{Introduction}

Within the masculinity and anti-school literature, it has been argued that educators must equip boys with the necessary capacities to interrogate gender binaries in how they construct their masculinities and adopt more inclusive ways of being male (Mac an Ghaill, 1994, p. 59; Skelton, 1997; Gilbert \& Gilbert, 1998; Mills, 2001). It is well 
documented that boys, particularly working-class boys, view music as a "feminised" subject and opt out of a musical education, when, actually, music arguably "provides an ideal medium through which dominant forms of masculinity can be problematised" (McGregor \& Mills, 2006, p. 222). In our contemporary society, boys increasingly find themselves attempting to negotiate successful learner identities in environments shaped by neoliberal reforms with a very narrow definition of success. We contend that the neoliberal agenda has a tremendous influence on their habitus, their masculine identities, and their learner identities (Francis, 2006; Burke, 2007; Phoenix, 2004; Davies, Saltmarsh, 2007). Often ill-equipped and lacking the necessary capitals to achieve academic success, the experiences of feeling devalued within the disadvantaged in formal learning environments can lead to the development of strategies of resistance (Mac an Ghaill, 1988; Jackson, 2003) and this dynamic, we argue, is a salient factor in the limited achievement of working-class boys.

Interestingly, the element that has largely been absent from the literature, concerning working-class boys and underachievement, is what boys actually want to achieve and how their engagement with (or, as often as not, disengagement from) achievementoriented activities shape their masculine habitus (Connolly, 2006a; Atencio, Beal \& Wilson, 2009) as well as school-based behaviours (Francis, 2006). By not exploring where boys achieve and what this achievement means to them, we know little about how and what boys prioritise in terms of skill-based learning. Our research explores such lacunae. Through this exploration, we touch on recent theorizing around the relationship between gender identity and habitus (McNay, 1999; Thorpe, 2010; Adkins, 2003). In accessing the boys' conception of a "successful learner" and how a masculine habitus 
was significantly altered, we draw upon Coles' (2009) persuasive extension of Bourdieu's (2001) Masculine Domination, in which he argues for the study of a "field of masculinity" where "[w]ithin the field of masculinity, there are sites of domination and subordination, orthodoxy (maintaining the status quo) and heterodoxy (seeking change), submission and usurpation" (p. 36).

We recognize how gender identity and music-making are interrelated and mutually informing (Harrison 2001; Harrison 2010; Feer 2009). We also recognise that identity work is more complex and contextual than simple expressions or manifestations of protest masculinities (Connell, 2005) or explanations of embracing laddish or bad-boy masculinities (Jackson, 2003). As a result, we also consider how habitus can help us understand the interworkings of gender identity (cf. Adkins, 2003; Coles, 2008; McLeod, 2005; 2009; Connolly, 2006a; McNay, 1999; Skeggs, 2002), specifically in relation to learner identities (Reay, 1995). Bourdieu believed formal schooling serves as a "productive locus" which gives rise to "certain patterns of thought" (Nash, 1990, p. 435). In the light of the data, we attempt to show how working-class boys' identity, as learners, functions in positive, non-hierarchical environments and how such environments give rise to new "patterns of thought" and new identity repertoires.

\section{Using Bourdieu's Tools}

In our investigation of the "social and symbolic value of music" (Burnard, 2012, p. 100) amongst young DJs and MCs, we employ habitus, as a tool, to explore how these young men "are simultaneously unique individuals with agency and subjects who are produced by their structural locations in the sense that their ways of thinking about and engaging with the world are strongly inflected by the world around them" (Archer et. al, 
2010, p. 31). Habitus, as ways of thinking, feeling, and being, is shaped by structural contexts and experiences. Habitus is:

A system of durable, transposable dispositions, structured structures predisposed to function as structuring structures, that is, as principles which generate and organize practices and representations that can be objectively adapted to their outcomes without presupposing a conscious aiming at ends or an express mastery of the operations necessary in order to attain them. (Bourdieu, 1990, p. 53)

In using habitus as a conceptual tool, it is essential to acknowledge how it is influenced greatly by different fields and by capitals and that it contains many (conflicting) dispositions which are brought to the forefront, depending on the field(s). How habitus functions in relation to field and capital has been noted in other studies with working-class boys and learning environments (cf. Ingram, 2009; Connolly, 2006b; Stahl, 2014). In her study of working-class boys in Belfast, Ingram (2009) argues: “... learning and schooling are enmeshed. If you oppose one, you oppose the other" (p. 429) and, therefore, our focus is on peer-led learning outside the school, which presented a field in which our participants could explore other forms of masculinity (Stahl \& Dale, 2012, 2013).

Despite the conceptual challenges, which arise from the complex interconnections of field, capital and habitus in learning cultures (Perkins, 2013), as well as the debates regarding the role of gender in the habitus (McNay, 1999; Adkins, 2003), we contend that Bourdieu's theoretical tools remain valuable for the kinds of analyses of identity work we undertook in our study. Indeed, in this case study, we challenge dominant accounts of 
'fixed' working-class urban masculinities precisely by showing the vacillation of dispositions occurring within the habitus of these young men: in a sense, we found that the boys had a different habitus for quotidian school work as compared with the habitual learning of music skills, which they were undertaking in their bedrooms and local youth centres. We are interested in how "dispositions and taken-for-granted ways of thinking and behaving" are generated by the environment around school boys, wherein certain forms of masculinity "are made possible, and actually only exist in, the context of the school" (Connolly, 2006b, p. 149).

\section{The Study}

Our research project explores how a set of boys were eager to advance their musical skills in making urban hardcore dance music, by participating in a one-hour after-school DJ club once a week and other extracurricular opportunities beyond the school context. In contrast to their formal, standards-driven schooling, music production was a field where the boys felt successful, valued, and where they functioned as adept learners and teachers. Similar to Feer's (2009) work on choir boys, motivation and optimal experiences, the experience of the boys were framed by "high levels of both perceived challenge and perceived skill, a clarity of goals, deep personal involvement and concentration, self-directedness, self-awareness..." (142). As spaces where 'identity work' practices were reshaped around learning, peer-led learning cultures provided a rare glimpse of collaborative, rather than competitive, attitudes. These were sites where, in keeping with Burnard's description of DJing, we were witness to "an amalgamation of style and sound arising from sociospatial performance creativities that emerge as a cocreated musicalized marking-out of urban spaces" (2012, p. 103). Our participants, who 
were labeled as "disaffected" from formal schooling, demonstrated tremendous dedication in their learning cultures, engaging in practices to foster capitals in order to cultivate their music skills, which they were then able to operationalize in their learner identities.

The case study school lies in a section of a northern city in England where unemployment has been endemic for decades, impacting enormously upon masculinity identity construction (cf. Nayak, 2006; Willis, 1977). Winlow (2001), in his vivid description of how post-industrialisation has reshaped masculinity, contends that where men once expressed their masculinity through 'shop floor masculinity', which involved "strength, skill autonomy, camaraderie and the ability to provide for his family" (p. 38), current traditional modes of masculinity construction are out of reach and, therefore, "its component parts are sifted, sorted and evaluated and those that can be moulded to fit in with the new post-industrial and post-modern cultural habitat" (p. 67).

In order to explore identity work within this learning culture, three key access points were utilized: (1) daily skill-based practices of young DJers/MCers and how these practices are validated within the learning culture; (2) performance and identity in the practices of individual participants - constructed through their habitus and capital in relation to the learning culture; and (3) the practices within the learning culture and the contrast between such learning practices and formal schooling. Based on qualitative data collected from semi-structured interviews and observations with boys aged 14-16, our analysis focused on three intertwined key features of this specific learning culture. 


\section{Key Features of the Learning Culture}

Field, for Bourdieu, is the context in which practices take place. As researchers, it is important to emphasize the relational aspects of habitus and field as it is at this juncture that identity is formed (Reay, 2010). While participants were clearly caught up in contemporary neoliberal processes of individualistic "success" and "failure" in formal schooling, we contend that "such processes are both ameliorated and framed by an overreaching sense of, and commitment to, collectivity and 'the common good"' which has been noted in studies focused on the educational experience of working class students and identities as learners (Reay, 2003, p. 305; Skeggs, 2002, 2004). After all, the habitus carries the "residue of specific cultural, social, and personal histories" (Atencio, Beal \& Wilson, 2009, p. 5) and this is particularly true of the white working-class attachment to tradition and belonging (cf. Lawler, 2012). This caring masculinity is shaped by a more traditional working-class masculine culture, such as anti-pretentious humour, dignity, honour, loyalty and caring, pride and commitment to employment (cf. Winlow, 2001; Skeggs, 2004; Lawler, 2012). Within the field of the peer-led learning culture, this form of masculinity became a core disposition; furthermore, it became an axis that both social and learner identities and aspirations were shaped upon.

\section{Performance and identity}

With DJs sticking to two very fast styles (Makina and Scouse) and only occasionally dipping into elements of R \& B, the lyrics become the background whilst the beats remain at the foreground. Overall, the content of the raps seemed to us to be subordinate to the simple fact of performance: the boys, some of whom were exceptionally hesitant and uncertain in conversation as well as having greatly restricted levels of literacy, 
seemed to just enjoy performing in front of a small group of peers, as is noted in other studies with boys and music (Freer 2009; Green 1997). The raps themselves, though often repetitive and basic, showed that these boys can express themselves in impressively confident ways, especially when the situation is non-hierarchical and supportive. For many of the boys, particularly the ones who were more proficient, making the moment was a real challenge to aspire to:

Challenging because like the scene ...the scene always changes - so like you bomb it and you're like mixing Makina and then the next minute you're mixing something else like. I've got to go with the flow sort of thing. (James)

It's hard to like mix two tunes in together. Get 'em both like match. Like, like 'cause it's harder and I think it makes the music sound better. Cause if it's just one tune then it's just one tune, but if you mix both tunes than it obviously gives you a completely different sound altogether, innit. (Jack)

It depends on-you see it depends on the tune sometimes. If it's not a good tune then you can't [MC] it. 'Cause I've been with me mates and someone's been DJing and put a tune on that I don't like and racked up. Lost, lost. (Jordan)

Yea, yea, yea - well, when you're mixing yea well people will like 'cause it's up to you really. If you start to budge-up or something then everyone's like 'go 
away'... it kinda just ruins the moment. If you're doing like good, like doing everything well there's no reason why people won't like praise you and that. (Scott)

What is also intriguing is that through perfecting their craft, particularly DJing, the boys are pushed to try music they would not normally listen to, typically R \& B: 'I used to listen to rave. Now I like $R \&$ B.' (James) and 'Like Rihanna and all them lot. Mixing them sometime.' (Callum). While still remaining faithful to their hardcore dance roots, the boys thus became willing to recognise female/'feminine' singers and styles. It is notable, indeed, that the masculinity of the music - the often highly aggressive MCing style and the fast tempi of the music, with its thumping beat - effectively made the boys willing and able to display enthusiasm for a curriculum area which remains perceived as being somewhat effeminate and 'for the girls' (Green, 1997; Harrison 2010). Indeed, the boys appeared to begin to see their own skill progression as a reward in itself, as well as, in part at least, a potential escape route from a 'bad boys' masculinity:

GS: Do you think DJing/making music has influenced you or changed you?

Yea, 'cause one time I never used to think I was good at music - but when I started, when I started to get good like at making music. (James)

GS: Like DJing - has it changed the way you see yourself?

Yea, cause I used to get into trouble and that. Like mischief on the streets but like it just gets you into trouble really. (Glenn)

GS: Would you say the decks have changed you or not? 
Yea, cause I'm not on the streets ... Instead of getting into trouble and that.

(Glenn)

For the 'hard' boys in the study, this music was not only a way to legitimately escape the streets' 'trouble', but also a valid way to contend with the hegemonic or popular masculine identity: to express themselves without appearing weak and instead gaining significant subcultural capital. Because the 'hard boys' were making music, they were able to shift between alternative identity positions: the craft of DJing or MCing gave their position as musicians a certain authenticity. Harrison (2001) noted that to perform certain styles of music-making could reduce the exclusion from socialisation through bullying. 'Hard' hegemonic identities are difficult to fully evacuate from, yet Glenn's positive reference to his MCing, as a means with which to alter a 'fixed' street identity, is surely significant: he, like most of the boys in our study, was known in school and by the local police as a trouble maker, yet evidently MCing provided him with: a) a different way of seeing himself; b) feelings of success; and c) a socially acceptable route away from the label of trouble maker.

For Bourdieu, habitus "contributes to constituting the field as a meaningful world, a world endowed with sense and value, in which it is worth investing one's energy" (Bourdieu \& Wacquant, 1992, p. 127). As a result of "the internalization of external structures, habitus reacts to the solicitations of the field" (Bourdieu \& Wacquant, 1992, p. 18). More specifically, within the habitus, what has been "internalized are not only the rules of the field (social structure) with which an individual is engaged, but also his or her position in that field, together with the chance of succeeding, which is determined by the defining capital in that field and the volume and composition of an individual's own 
capital" (Yang, 2013, p. 6). Being the product of history and experience, habitus

may be changed by history, that is by new experiences, education or training (which implies that aspects of what remains unconscious in habitus be made at least partially conscious and explicit). Dispositions are long-lasting: they tend to perpetuate, to reproduce themselves, but they are not eternal. (Bourdieu, 2002, p. 29)

Using habitus as a conceptual tool, it has been noted, in other research, how workingclass males 'make sense' of the pervasive neoliberal rhetoric in schooling (Stahl, 2012, 2013, 2014). We found, in contrast to formal schooling, the field of the learning cultures, as a social field, allowed the habitus of these young men to orient toward the "communitarian rather than individualistic" (Reay, 2003, p. 306). Furthermore, it brought forth a more caring and cathartic form of masculine identity centred on a passion for music making.

\section{'Class on the decks': the importance of technical skill}

Understood as 'socialized subjectivity', the habitus Bourdieu describes is in interaction with the field, where it is learning the rules of the game and developing strategies accordingly (Bourdieu \& Wacquant, 1992). While DJing and MCing were partly practiced socially, the boys indicated that both DJing and MCing were also practiced individually, typically at home in the boys' private spaces. All the boys were unequivocal about which DJs and MCs amongst them were 'pure class' ( i.e. excellent performers). Some boys viewed their individual music work as relaxing, while other boys in the study resisted defining their 'hobby' as 'relaxing', claiming it required time and 
effort. In contrast to previous work on disengaged boys in formal learning environments (Jackson, 2002; 2003, Epstein, 1998; Willis, 1977), we must stress that the boys were aware of their learning styles and how best to improve their craft. Some preferred to watch and learn, while some needed hands-on teaching and feedback through peers, family members, or in youth groups, some of which offered tuition on the decks. The passing down from one generation to another was referenced multiple times in the data set:

'Aye. My Dad used to do DJing in like nightclubs and all that. He teaches us.' (Callum).

I always think... doing something for meself. I can't like learn off like other people. It applies more to the decks because they can teach you how to put in a beat and that but then you have to learn from there yourself. (Glenn)

We observed some signs of a desire amongst the boys to spread their enthusiasm for the music: 'Dunno. I would just-just want people to like get into it. Like people who didn't do it. On the scene like. I just want people to get into it' (Glenn B.). Feer (2009) notes how boys thrive on immediate feedback, where,

Closely related to feedback about processing is feedback about self-regulation. When students monitor, direct and regulate actions toward specific learning goals, they exhibit qualities associated with autonomy, self-control, self-direction, and selfdiscipline. (150) 
Feedback, in this case, involved some 'battles' akin to those described by Harkness

(2011), but these were not especially aggressive; rather, we saw signs that the boys would monitor the progress of their own skills, exhibit self-control around specific goals, as well as those of their peers. Coles (2009) argues that a field of masculinity is centred around the legitimacy of specific capitals, where "those in dominant positions strive to conserve the status quo by monopolizing definitions of masculinity and the value and distribution of capital, while subordinate challengers look to subversive strategies, thus generating flux and mechanisms for change" (p. 36); however, we found less severe operations at play in the field of masculinity. Away from the neoliberal processes of the school environment, the masculinity identity, which we argue to be caring and cathartic, was focused more about the improvement of skills and less about competition and legitimacy. $^{2}$

GS: How do you know your skills have improved?

Because I've beat - I've been out at like my cousins and he's had decks and me and my mates would be on them. And they'd tell us if I've got better. (Jordan)

Not really a competition really - I wouldn't really like say it to people that I'm betta. Basically if I'm good, I'm good. That's at the end of the day really. (Jordan)

GS: Is there an element of competition tied to music or not? 
Sometimes between me and my mates like Flash [Jordan E] will beat me - like you know Joe N? He'll always beat me but ... there is sometimes but not all the time.

PD: But Jordan always beats you ...

Aye, Joe - he's class on the decks.

PD: He is pretty good at it.

GS: So is it like a friendly competition?

Aye, friendly like - no one like - I don't know how to put it - no one like angry like but just like having a competition. (Callum)

Interestingly, the boys recognized that 'battles' also allow skills to develop through a combined effort, between DJs and MCs, to establish and prolong 'the moment.' The importance of the moment or 'break' is grounded in DJing as a practice. Extending a break is a cornerstone of all modes of 'turntablism' (to use the internationally-known term) from the earliest days of hip hop onwards. Although the DJs in our study were certainly not spinning 'breakbeats' in the hip hop sense, they were highly attuned to the importance of the 'breakdown' and 'kick-off' sections endemic to the hardcore dance 'tunes' they based their 'sets' around.

Bourdieu (1992) argues that symbolic capital is valued and accumulated according to the logics and practices which comprise each social field, where individuals (and groups) struggle over "embodied meanings and practices which constitute the social field/s, and where positions of power are delineated according to prevailing ways in which the 
embodied self is recognized and legitimized" (Atencio, Beal \& Wilson, 2009, p. 4). As with Burnard's (2012, p. 107-110) case study of the Taiwanese celebrity DJ, XUAN, who is able to actively construct the club habitus through his 'feel for the game', we do not discount the power of the field, as these boys are both conditioned and attuned to the social. However, while practice becomes a process of drawing clear distinctions, we saw very little evidence of a fierce 'competition for capitals' in order to improve one's own standing and legitimacy within this particular cultural field as - it would appear - the logic of the field was not structured in that way.

PD: So it is kinda like team-work...

Ay. Say like it was like two people MCing together then sometimes there're like this thing you could do. Like if you work together ... like MCers have like rhymes which they say. If they're friend gets to know that rhyme then maybe like pause and then at the end of their rhyme - and his friend had finished off his rhyme. So it sounds like good together.

Like I have my decks in me bedroom and I'll have like 5 to 6 people in sometimes if me ma allows it. But when we're sitting they're all like 'that's lethal' like 'send us this on me phone' and all that ... and so like praise you a bit when you're doing good stuff. (Scott)

While the boys did strive to be the best at their craft, they did not seek to be better than other people - rather the culture seemed to be shaped by the ability to make a significant musical contribution. Competition was important, but there was consensus that it was 
'friendly' competition, experienced within a fairly supportive environment where the skill of the music-making was considered to be self-evident. There are echoes here of an egalitarian habitus (Stahl, 2014), where working-class boys developed dispositions centred upon a narrative of 'no one is better than anyone else' or 'above their station' (cf. Lawler, 1999; Archer \& Leathwood, 2003). As Bourdieu makes clear, "when habitus and field do not accord, there are inevitable conflicts and disjunctures" (Reay, 2002), but in a peer-led learning environment, the habitus and field are closely aligned, whereas in the boys' formal schooling the disjunctures are more divisive. As a result, they tap into specific repertoires of 'hard' masculinity as their social positioning is more vulnerable. In their schooling, working-class students may find their habitus "pulled" in incompatible directions (cf. Ingram, 2009; Stahl, 2013). When the habitus and field do not align, "[s]uch experiences tend to produce a habitus divided against itself, in a constant negotiation with itself and with its ambivalence and, therefore, doomed to a kind of duplication, to a double perception of self, to successive allegiances and multiple identities" (Sayer, 2005, p. 26).

\section{Happy hardcore: positively raving}

The DJs and MCs felt that the craft of music-making empowered them and gave them a 'buzz', or prolonged feelings of happiness, not present in their formal schooling.

Happy. Just makes us better. Cheers us up. (Callum)

It makes you feel betta. (Glenn)

GS: Ok, in making [music] what emotions do attach to making music? 
Happiness sort of thing because it's like a cool thing to do ... like changing ... like with like one tune, then like two tunes then like your own tune. (James)

GS: When you're planning it out and before you put it on the decks, does it make you feel in a position of power when you're constructing or making music?

Sort of. It makes you feel like in control like sort of thing.

GS: Yea, I would think so as there's been work done on DJs in like proper clubs and how they can turn the tide of the club.

It's...it's like when you're doing it like - like dancing-you're in control of what they're doing to it - you do feel powerful when you're doing it. (James)

While it is imperative to understand how gender is constructed and regulated through power relations in schooling (Harrison 2010), it is also essential that we see how power relationships are formed through informal teaching and learning. Our data strongly suggests that when teaching and learning occurs within the peer-led learning cultures, a more cathartic and caring form of masculinity, within the matrix of dispositions, appreciations and action, comes to the surface of the habitus. If habitus is a "strategygenerating principle enabling agents to cope with unforeseen and ever-changing situations" (Bourdieu \& Passeron, 1977, p. 72), we consider habitus in the learning culture as a "generative structure" formed in relation to the music production, which values certain capitals (McNay, 1999).

\section{Discussion}

Burnard (2012) argues that underpinning the practice of DJing are three main things: “(i) the music's embodiment of social connection; (ii) the dialogical performance practice 
between DJs and audience; and (iii) a unique kind of critical listening and choosing, which is essential to the DJ's creativity" (p. 119). Throughout our work with these young DJers/MCers, we witnessed these practices to varying extents but, more specifically, the social interconnectedness between their identities, their creativities, and their sense of peer group validation. Bourdieu argues that symbolic capital is valued and accumulated according to the underpinning logics and practices, which constitute each social field and the broader collection of social fields. While, for Bourdieu, field always connotes a struggle for power and distinction, we found the peer-led learning culture of these working-class boys to be sites where hierarchical positions of power were less prevalent, as the collective nature of their learning culture became more noticeable. For example, we noted how MCs frequently 'passed the mic' at regular intervals, and the willingness of DJs to spontaneously and patiently guide younger and/or less experienced turntablists to improve their skills on the decks.

In their studies of all-male skate-boarding culture, Atencio, Beal \& Wilson (2009) building on the argument Bourdieu sets forth in Masculine Domination of linked masculinity with virility (understood as competition with other men) - argue that it is common with men, "who become associated with risk-taking behaviours and attitudes [to gain] symbolic capital because they were legitimized and recognized within the social field/s" (p. 10). While this may be common, in our research with MCers and DJers, we were witness to a variety of behaviours and identities, some relating to risk and most relating to legitimization; as there was no structural lag between the habitus and the field, elements of the working-class peer group conflated with the learning environment.

Throughout the study we asked how boys' practice and develop skills and construct 
their learner identities, in relation to learning outside the field of formal education where, we found, the felt binary of loutishness and passivity to not be apparent. Within our small case study school, the 'bad boy' anti-school masculine identity (Archer \& Yamashita, 2003, pp. 122-3) was a commonality that functioned both as a source of pride and as a burden for many, if not most, of the working-class boys. However, we found that bad-boy masculine identities, though potent, are not the only identity discourse drawn upon - their habitus seemed, rather, to be always "in process, multi-placed and shifting" (Martino \& Pallotta-Chiarolli, 2003, p. 9). In short, our evidence suggested that the particular habitus arising from the boys' practices as DJs and MCs allowed them to retain the respect of their peers yet, simultaneously, to work diligently and with absolute commitment as active learners of a craft.

Within the field of peer-led learning culture, there are conceptions of 'success' - or "making the moment" - but we have to consider these constructions alongside the development of boys' music skills as accruing valuable capitals. Overwhelmingly, the data shows that the boys consider MCing and, particularly DJing, to be a craft with varying levels of skill that can be developed over time. The creation of quality music within the field becomes a capital for the boys, which influences their habitus. Furthermore, such capitals can be operationalized to secure status and positioning. The peer-led teaching and learning of the skills of DJing and MCing within the space of the learning culture makes success manifest in unique ways, and these practices of learning influence the boys' masculine identity structures within both the field of music (Green, 1997) and the field of masculinity (Coles, 2009).

Using Bourdieu's concepts of habitus, field and capital to think relationally shows the 
ways in which the tools reveal how individuals become agentic within fields where they feel they have value. As Yang (2013) writes: "people who are inherently disadvantaged in a particular field would naturally adjust their aspirations (one embodiment of habitus) and very often turn to self-elimination without consciously assessing the real chances of success" (p. 6). We accept that the inclination to invest in a particular field depends not only on the amount of cultural capital alone (the skill of MCing/DJing), but also on the weight of cultural capital in the total volume of an individual's capital. The boys are interested in investing in developing their music skills not just because they want to achieve, but also because of the degree to which their peer validation is dependent on the learning of such skills.

\section{Conclusion}

Complete details of how the learning cultures functioned in relation to the boys' identity work (and vice-versa) are presented in Stahl \& Dale $(2012,2013)$. Our data shows that within their formal schooling, the working-class boys' habitus is exposed to competing fields which push them - to varying extents - to operationalise their capitals, as well as an unconscious "feel for the game" (Bourdieu, 1988, p. 782). Within their learning culture, we see the game is altogether different. While certain modes of masculinity may be prioritized by the formal schooling, these are mediated by the local community, the family and the peer group (Connolly, 2006b, p. 150), as well as, arguably, the practice of learning. Within practices of learning, the participants become agentic and operationalise capitals, but the operationalization, as a process, is more at the forefront of the identity work with which the boys engage.

We feel it is essential to consider that currently "enormous amounts of time, energies, 
and resources are being wasted on a merely reactive approach to boys' disruptions and violence", instead of education sites being "more pro-active in designing courses, programmes, and teaching approaches that begin to challenge the dominant courses ..." (Salisbury \& Jackson, 1996, p. 15). As musicians, these young men spend considerable amounts of time and energy honing their skills. It is through this process, we argue, that the transformative potential of this pedagogy is most apparent. If these boys can be perceived by their peers as successful in an activity which requires perseverance, skill, and verbal/linguistic dexterity, perhaps there is an opportunity to re-engage the disaffected in positive ways. This may, of course, require a re-consideration of what educational success is and, perhaps more importantly, how it can best be measured. We would argue that while it is important to challenge the dominant gender discourse explicitly (Mills, 2001), it is also important to know what excites boys, create spaces where diverse conceptions of masculinity can be represented, and recognize legitimate activities that build self-esteem.

\section{References}

Adkins, L. (2003) Reflexivity: Freedom or Habit of Gender? Theory Culture Society, $20(6), 21-42$.

Archer, L. \& Leathwood, C. (2003) New Times-Old Inequalities: diverse Workingclass femininities in education. Gender \& Education, 15(3), 227-235.

Archer, L. \& Yamashita, H. (2003) Theorising Inner-city Masculinities: 'race', class, gender and education. Gender and Education 15(2), 115-132.

Archer, L., Hollingworth, S. \& Mendick, H. (2010) 'The Street,' 'The Estate' and 'My Trainers': Social Class and Urban Education. In G. Grace, M. Maguire \& I. Menter. 
(eds), Urban Youth and Schooling. Berkshire: Open University Press.

Atencio, M., Beal, B. \& Wilson, C. (2009) The distinction of risk: urban skateboarding, street habitus and the construction of hierarchical gender relations. Qualitative Research in Sport and Exercise, 1(1), 3-20.

Bourdieu, P. \& Passeron, J.C. (1977) Reproduction in Education, Society and Culture. London: SAGE Publications.

Bourdieu, P. (1988) Vive la Crise! For Heterodoxy in Social Science. Theory and Society, 17(5), 773-787.

Bourdieu, P. (1990) The logic of practice. trans. R. Nice Cambridge: Polity Press.

Bourdieu, P. (2001) Masculine Domination. Oxford: Blackwell Publishers Ltd.

Bourdieu, P. \& Wacquant, L. (1992) An Invitation to Reflexive Sociology. Cambridge: Polity Press.

Burke, P. (2007) Men accessing education: masculinities, identifications and widening participation. British Journal of Sociology of Education, 28(4), 411-424.

Burnard, P. (2012) Musical Creativities in Practice. Croydon: Oxford University Press.

Coles, T. (2008) Finding space in the field of masculinity: lived experiences of men's masculinities. Journal of Sociology, 44(3), 233-248.

Coles, T. (2009) Negotiating the Field of Masculinity: The Production and Reproduction of Multiple Dominant Masculinities. Men and Masculinities, 12(1), 30-44.

Connolly, P. (2006a) The effects of social class and ethnicity on gender differences in GCSE attainment: a secondary analysis of the Youth Cohort Study of England and Wales 1997-2001. British Educational Research Journal, 32(1), 3-21.

Connolly, P. (2006b) The Masculine Habitus as ‘Distributed Cognition’: A Case Study of 
5- to 6-Year-Old Boys in an English Inner-City, Multi-Ethnic Primary School. Children \& Society, 20(2), 140-152.

Connell, R. W. (2005) Masculinities. Cambridge: Blackwell Publishers Ltd.

Davies, B. \& Saltmarsh, S. (2007) Gender economies: literacy and the gendered production of neo-liberal subjectivities. Gender and Education, 19(1), 1-20.

Epstein, D. (1998) Real boys don't work: 'underachievement', masculinity and the harassment of 'sissies'. In D. Epstein, J. Elwood, V. Hey \& J. Maw (eds), Failing Boys? Issues in gender and achievement, Buckingham: Open University Press.

Francis, B. (2006) Heroes or Zeroes? The discursive positioning of 'underachieving boys' in English neo-liberal education policy. Journal of Education Policy, 21(2), 187-200.

Freer, T. (2009) Boys descriptions of their experiences in choral music. Research Studies in Music Education, 31(2), 142-160.

Gilbert, R. \& Gilbert, P. (1998). Masculinity Goes to School. Routledge.

Green, L. (1997) Music, Gender, Education. Cambridge: Cambridge University Press. Harkness, G. (2011) Backpackers and Gangstas: Chicago's White Rappers Strive for Authenticity. American Behavioral Scientist, 55(1), 57-85.

Harrison, S.D. (2001). Real men don't sing. Australian Voice, 11, 31-36.

Harrison, S. (2010). Boys on the Outer: Themes in Male Engagement with Music. Thymos: Journal of Boyhood Studies, 4(1), 39-53.

Ingram, N. (2009) Working-class boys, educational success and the misrecognition of working-class culture. British Journal of Sociology of Education, 30(4), 421-434.

Jackson, C. (2002) "Laddishness" as a Self-worth Protection Strategy. Gender and Education, 14(1), 37-50. 
Jackson, C. (2003) Motives for 'Laddishness' at School: Fear of Failure and Fear of the 'Feminine'. British Educational Research Journal, 29(4), 583-598.

Lawler, S. (1999) 'Getting out and Getting Away': Women's Narratives of Class Mobility. Feminist Review, 63(3).

Lawler, S. (2012) White like them: Whiteness and anachronistic space in representations of the English white working class. Ethnicities, 12(4), 409-426.

Mac an Ghaill, M. (1988) Young, gifted and black: Student-teacher relations in the schooling of black youth. Milton Keynes: Open University Press.

Mac an Ghaill, M. (1994) The Making of Men: Masculinities, Sexualities and Schooling. Buckingham: Open University Press.

Martino, W. \& Pallotta-Chiarolli, M. (2003) So What's a Boy? Maidenhead: Open University Press.

Mills, M. (2001) Introduction: challenging violence in schools as an issue of masculinity. D. Epstein \& M. Mac an Ghaill (eds), Challenging Violence in Schools: An Issue of Masculinities. Buckingham, Philadelphia, Open University Press: 1-18.

McLeod, J. (2005) Feminists re-reading Bourdieu: Old debates and new questions about gender habitus and gender change. Theory and Research in Education, 3(1), 11-30.

McLeod, J. (2009) Youth Studies, Comparative Inquiry, and the Local/Global Problematic. Review of Education, Pedagogy, and Cultural Studies, 31(4), 270-292.

McGregor, G. \& Mills, M. (2006) Boys and music education: RMXing the curriculum. Pedagogy, Culture \& Society, 14(2), 221-233.

McNay, L. (1999) Gender, Habitus and the Field: Pierre Bourdieu and the Limits of Reflexivity. Theory, Culture, Society, 16(1), 95-117. 
Nash, R. (1990) Bourdieu on Education and Social and Cultural Reproduction. British Journal of Sociology of Education, 11(4), 431-447.

Nayak, A. (2006) Displaced Masculinities: Chavs, Youth and Class in the Post-industrial City. Sociology, 40(5), 813-831.

Perkins, R. (2013) Learning cultures and the conservatoire: An ethnographicallyinformed case study. Music Education Research, 15(2), 196-213.

Phoenix, A. (2004) Neoliberalism and Masculinity: Racialization and the Contradictions of Schooling for 11-to-14-Year-Olds. Youth Society, 36(2), 227-246.

Reay, D. (1995) 'They Employ Cleaners to Do That': Habitus in the Primary Classroom. British Journal of Sociology of Education, 16(3), 353-371.

Reay, D. (2002) Shaun's Story: Troubling Discourses on White Working-class Masculinities. Gender and Education, 14(3), 221-234.

Reay, D. (2003) A Risky Business? Mature Working-class Women Students and Access to Higher Education. Gender and Education, 15(3), 301-317.

Reay, D. (2010) Identity Making in Schools and Classrooms. In M. Wetherall \& C. Talpade Mohanty (eds), The Sage Handbook of Identities. Los Angeles, London, New Delhi: SAGE, 277-294.

Sayer, A. (2005) The Moral Significance of Class. Cambridge: Cambridge University Press.

Skelton, C. (1997) Primary Boys and Hegemonic Masculinities. British Journal of Sociology of Education, 18(3), 349-369.

Skeggs, B. (2002) Formations of Class \& Gender. Nottingham: SAGE Publications. Skeggs, B. (2004) Class, Self, Culture. London: Routledge. 
Stahl, G. (2012) Aspiration and a Good Life among White Working-Class Boys in London. Journal of Qualitative and Ethnographic Research, 7(8-9), 8-19.

Stahl, G. (2013) Habitus disjunctures, reflexivity and white working-class boys' conceptions of status in learner and social identities. Sociological Research Online, $18(3)$.

Stahl, G. (2014) Aspiration, Identity and Neoliberalism: Educating White Working-Class Boys. London: Routledge.

Stahl, G. \& Dale, P. (2012) Creating Positive Spaces of Learning: DJers and MCers Identity Work with New Literacies. The Educational Forum, 76(4), 510-523.

Stahl, G. \& Dale, P. (2013) Success on the decks: working-class boys, education and turning the tables on perceptions of failure. Gender \& Education, 25(2), 1-16.

Thorpe, H. (2010) Bourdieu, Gender Reflexivity, and Physical Culture: A Case of Masculinities in the Snowboarding Field. Journal of Sport \& Social Issues, 34(2), 176214.

Salisbury, J. \& D. Jackson (1996) Challenging Macho Values: Practical Ways of Working with Adolescent Boys. London: The Falmer Press.

Willis, P. (1977) Learning to Labour: How working class kids get working class jobs. New York: Columbia University Press.

Yang, Y. (2013) Bourdieu, Practice and Change: Beyond the criticism of determinism. Educational Philosophy and Theory, 45, 1-19. 